\title{
FERMENTASI ALAMI IKAN KAYU (ARABUSHI) CAKALANG (Katsuwonus pelamis) DAN TONGKOL (Auxis thazard) DALAM DESIKATOR
}

\author{
Jamal Basmal"), Ninoek Indriati*), Nurul $\mathrm{Hak}^{*}$ dan Suyuti Nasran
}

\begin{abstract}
ABSTRAK
Percobaan fermentasi alami ikan kayu (arabushi) cakalang (Katsuwonus pelamis) dan tongkol (Auxis thazard) menjadi katsuobushi telah dilakukan di dalam desikator berdiameter $29 \mathrm{~cm}$ dan tinggi $26 \mathrm{~cm}$. Arabushi disusun di dalam desikator secara bersilangan dan untuk meningkatkan kelembaban relatif udara ruangan fermentasi diletakkan kapas yang telah dibasahi dengan air sebanyak $50 \mathrm{~mL}$ pada dasar desikator. Fermentasi dilakukan melalui lima tahap dan setiap tahap diakhiri bila kapang tumbuh merata dan telah terjadi perubahan warna kapang dari putih menjadi abu-abu kehijauan atau abu-abu. Hasil percobaan fermentasi arabushi menjadi katsuobushi cakalang dan tongkol menunjukkan terjadinya penurunan kadar fenol sebesar 4,9\%bk (bobot kering) dan 3,8\%bk, nilai aktivitas air $\left(\mathrm{a}_{\mathrm{w}}\right)$ katsuobushi cakalang cenderung konstan sebesar 0,87, sedangkan katsuobushi tongkol cenderung menurun dari 0,84 menjadi 0,81 setelah akhir fermentasi tahap V. Jumlah protein kasar yang dapat diuraikan menjadi asam-asam amino sederhana sebesar 13,69\%bk dan 80,75\%bk masing-masing untuk katsuobushi cakalang dan tongkol. Jenis asam amino yang tidak terdeteksi selama proses fermentasi pada katsuobushi cakalang adalah asam amino alanin, leusin, dan fenilalanin, sedangkan pada katsuobushi tongkol hanya asam amino prolin. Jenis kapang yang tumbuh selama tahapan fermentasi adalah Eurotium repens, Aspergillus flavus, Penicillium citrinum, dan Penicillium spp.
\end{abstract}

ABSTRACT Natural fermentation of dried fish stick (arabushi) skipjack tuna (Katsuwonus pelamis) and frigate mackerel (Auxis thazard) in desiccator. By: Jamal Basmal, Ninoek Indriati, Nurul Hak, and Suyuti Nasran.

The experiment on the natural fermentation of dried fish stick (arabushi) of skipjack tuna (Katsuwonus pelamis) and frigate mackerel (Auxis thazard) was carried out in a desiccator with $10 \mathrm{~cm}$ height, and $40 \mathrm{~cm}$ diameter. Arabushi was arranged in desiccator in which cotton sheets that have been moisted with $50 \mathrm{ml}$ tap water were laid down on the bottom of desiccator. Natural fermentation was carried out 5 steps. Every step of fermentation was stopped when moulds completely covered the surface of arabushi and colour change from white to gray greenish or grayish occurred. The result of fermentation showed that phenolic content of dried fish skipjack tuna and frigate mackerel decreased during natural fermentation i.e. 4,9\% db (dry basis) and $3,8 \% d b$, respectively. A value of skipjack tuna tend to be constant by 0.87 , while frigate mackerel decreased from 0.84 to 0.812 . Total crude protein digested to simple amino acids were $13.69 \% \mathrm{db}$ and $80.75 \% d b$ for skipjack tuna and frigate mackerel katsuobushi. Decomposition of peotein into amino acids such as alanine, leusine, and phenylalanine occurred on the skipjack mackerel katsuobushi, while proline was occured during fermentation of frigate mackerel. Species of moulds grew on the surfaces of both arabushi were Eurotium repens, Aspergillus flavus, Penicillium citrinum and Penicillium spp.

KEYWORDS: arabushi, katsuobushi, moulds, fermentation.

\section{PENDAHULUAN}

Ikan kayu (katsuobushi) adalah salah satu bentuk produk perikanan yang telah mengalami proses perebusan, pengeringan, pengasapan, dan fermentasi berulang kali menggunakan jenis kapang spesifik yang bertujuan untuk memperbaiki nilai gizi, citarasa dan aroma serta untuk tujuan pengawetan (Tanikawa, 1971; Winarno et al., 1980), sedangkan arabushi adalah ikan yang telah mengalami perlakuan seperti katsuobushi, tetapi tidak dilakukan fermentasi. Keuntungan melakukan fermentasi berulang-ulang adalah untuk mendapatkan aroma dan citarasa spesifik ikan kayu, karena salah satu bentuk penentuan kualitas katsuobushi yang dihasilkan ditentukan oleh jumlah tahapan fermentasi, kemampuan kapang tumbuh menutupi permukaan arabushi

\footnotetext{
*) Peneliti pada Balai Penelitian Perikanan Laut
} 
dan jenis kapang. Tanikawa (1971) serta Doi et al. (1989a,b dan 1990) menemukan beberapa spesies Aspergillus pada proses fermentasi arabushi menjadi katsuobsuhi yaitu $A$. repens (lima strain), A. glaucus (empat strain) dan $A$. candidus (dua strain). Onions et al. (1981) dalam deskripsinya memasukkan $A$. repens bersamasama dengan $A$. echinulatus, $A$. amstelodemi dan A. chevalieri ke dalam kelompok $A$. glaucus.

Jenis ikan yang umum digunakan untuk pembuatan ikan kayu adalah ikan cakalang (Katsuwonus pelamis), tongkol (Euthynus spp.), madidihang (Thunnus albacore), serta berbagai jenis ikan pelagik kecil seperti ikan layang (Decapterus spp.) dan lemuru (Sardinella spp.) (Tanikawa, 1971; Nasran, 1988; Hanafiah et al., 1984). Di beberapa daerah seperti Sulawesi Utara, Maluku dan Irian Jaya telah dilakukan pengolahan ikan cakalang menjadi arabushi untuk diekspor ke beberapa negara dan biasanya proses pembuatan katsuobushi dilakukan di negara tujuan pada hal nilai tambah terbesar adalah bila arabushi dapat diolah menjadi katsuobushi.

Diketahui bahwa negara-negara tropis seperti Indonesia mempunyai beragam jenis kapang yang dapat dimanfaatkan untuk pembuatan katsuobushi dengan syarat kondisi tumbuh yang diinginkan harus memenuhi syarat tumbuh. Sifat kapang menyukai kondisi like-wet yakni akan tumbuh sempurna di permukaan arabushi bila kondisi lingkungan memenuhi syarat, dalam hal ini tingkat kelembaban dan jumlah uap air dalam ruangan fermentasi harus tinggi, suhu tidak terlalu tinggi, serta nutrisi medium tumbuh harus sesuai.

Hanafiah et al. (1984), Nasran \& Irianto (1987) serta Basmal et al. (1997a dan 1997b) menemukan beberapa kendala yaitu kapang tidak tumbuh atau waktu yang diperlukan untuk tumbuh di permukaan arabushi masih relatif cukup lama. Selanjutnya dikatakan bahwa faktor ekternal ( $\mathrm{RH}$, jumlah uap air dan suhu) dan faktor internal (nilai $\mathrm{a}_{\mathrm{w}}$, dan kadar air) sangat menentukan laju pertumbuhan kapang pada permukaan arabushi. Pada fermentasi yang dilakukan secara alami dengan tidak mengontrol laju kecepatan penguapan air dan tingkat kelembaban udara di dalam ruangan fermentasi sulit melakukan pengontrolan pertumbuhan kapang. Oleh sebab itu fermentasi dilakukan di dalam ruangan kedap air (desikator) dengan harapan tingkat kelembaban dan jumlah uap air dapat meningkat.

Tujuan penelitian ini adalah untuk mempelajari kemampuan kapang alami tumbuh pada permukaan ikan kayu di dalam ruangan yang mempunyai tingkat kelembaban dan suhu yang lebih tinggi dari sekitarnya. Di samping itu, juga untuk mempelajari kemampuan kapang melakukan degradasi protein, lemak, dan kadar fenol serta perubahan kadar air dan nilai $a_{w}$ selama proses fermentasi.

Diduga perbedaan jenis kapang alami yang tumbuh pada kedua jenis arabushi mempunyai kemampuan yang berbeda pula dalam mengubah keseimbangan asam amino dan kadar fenol. Untuk itu pendekatan yang dilakukan adalah membiarkan kapang tumbuh secara alami di permukaan arabushi hingga merata, sampai terjadi perubahan warna kapang dari warna putih menjadi hijau keabu-abuan/hijau kebiru-biruan pada setiap tahap fermentasi.

\section{BAHAN DAN METODE}

\section{Bahan}

Jenis ikan yang digunakan dalam penelitian ini adalah ikan cakalang ( $K$. pelamis) berukuran 2,5-3,0 kg dengan rata-rata bobot per ekor adalah $2,8 \mathrm{~kg}$ dan tongkol ( $A$. thazard) berukuran antara 0,5-1,5 kg/ekor dengan rata-rata bobot per ekor $0,8 \mathrm{~kg}$. Ikan-ikan ini diperoleh dari nelayan Pelabuhanratu yang ditangkap dengan jaring payang dan lama penangkapan tidak lebih dari enam jam. Kondisi ikan masih segar (rigor), mata cerah, insang merah dan berbau rumput laut segar, tekstur daging kompak dan belum terlihat adanya pemisahan antara lapisan daging, penampakan ikan cerah spesifik ikan cakalang dan bagian perut tidak pecah. Ikan dibawa ke Instalasi Penelitian Perikanan Laut Slipi dalam keadaan segar menggunakan es balok yang telah dihancurkan dengan perbandingan ikan : hancuran es adalah 1 : 1 , sedangkan arang dan batok kelapa yang digunakan sebagai sumber asap dan energi panas diperoleh dari pasar.

\section{Metode}

Arabushi diolah dengan menggunakan metode yang telah dikembangkan oleh Nasran \& Irianto (1987). Pertama-tama ikan dibuang kepala dan isi perut, kemudian difilet. Filet ikan direbus pada suhu $80-90^{\circ} \mathrm{C}$ selama 90 menit. Selanjutnya dilakukan kombinasi pengeringan dan pengasapan panas di dalam ruangan asap hingga kadar air mencapai antara 17\%-20\%. Pada pembuatan arabushi ikan tongkol dibelah dua (kamebushi) dan ikan cakalang dibagi menjadi empat, setiap bagian disebut loin (honbushi).

Arabushi yang dihasilkan difermentasikan secara alami di dalam ruangan kedap udara 
(desikator) berukuran tinggi $26 \mathrm{~cm}$, dan diameter $29 \mathrm{~cm}$. Waktu fermentasi tergantung pada kemampuan kapang tumbuh merata dan terjadinya perubahan warna dari putih menjadi hijau keabuabuan/hijau kebiru-biruan. Setelah kapang tumbuh dengan sempurna dilakukan penjemuran di bawah sinar matahari selama 60 menit, kemudian kapang yang menempel di permukaan arabushi disikat. Proses fermentasi ini dilakukan hingga lima tahap dan setiap tahap memerlukan waktu tujuh hari. Pada Gambar 1 dapat dilihat diagram pembuatan katsuobushi.

Untuk meningkatkan kelembaban relatif ruangan fermentasi (desikator), kapas (10 g) yang

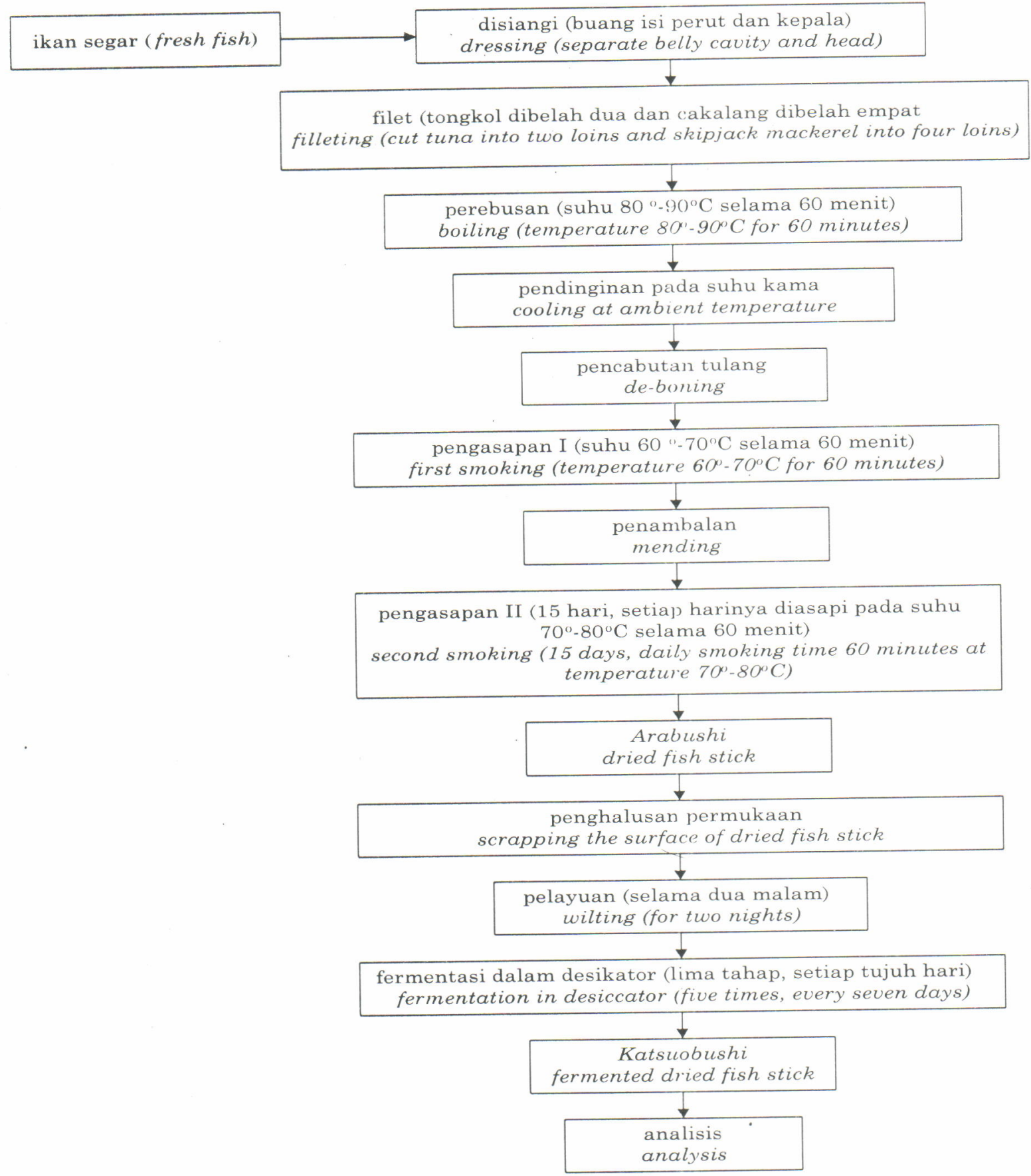

Gambar 1.Diagram pembuatan katsuobushi.

Figure 1. Processing flow diagram of katsuobushi. 
telah dibasahi dengan air sebanyak $50 \mathrm{~mL}$ diletakkan pada dasar desikator dengan jarak arabushi dengan kapas $\pm 5 \mathrm{~cm}$. Arabushi disusun di atas lempengan porselen berlubang secara bersilangan; sebanyak 10 loin untuk setiap perlakuan. Setiap empat hari sekali dilakukan perubahan susunan arabushi dengan tujuan untuk menghindarkan kelembaban yang terlalu tinggi pada arabushi paling bawah. Di samping itu penyusunan kembali dimaksudkan untuk menghindarkan jangan sampai terjadi udara jenuh di dalam ruangan fermentasi.

Setiap akhir tahap fermentasi dilakukan analisis yang meliputi pengujian kadar fenol menggunakan metode Horwitz (1980), nilai $\mathrm{a}_{\mathrm{w}}$ menggunakan $\mathrm{a}_{\mathrm{w}}$-meter merek aw-Wert-Messer, identifikasi jenis kapang yang tumbuh menggunakan metode Piit \& Hocking (1985) dan Samson et al. (1995). Kandungan asam amino ditentukan menggunakan instrumen Shimadzu DU-Port high performance pressure liquid chromatographi LcA dengan coulumn ISC-07/S1504. Ikan segar, arabushi dan katsuobushi hasil fermentasi tahap $\mathrm{V}$ dianalisis proksimat (kadar air, lemak dan protein), dengan metode Anonim (1974) dan nila $a_{w}$ Perbedaan suhu bola basah dan kering dicatat menggunakan alat pencatat suhu (thermorecorder) sedangkan perbedaan suhu bola basah dan kering tersebut diinterpretasikan ke dalam psychrometric chart untuk menghitung jumlah kelembaban relatif udara dan uap air dalam ruangan fermentasi.

\section{HASIL DAN BAHASAN}

\section{Pembuatan arabushi}

Hasil pengujian arabushi terhadap kadar fenol, air dan protein kasar dari arabushi cakalang dan tongkol menunjukkan adanya perbedaan nyata. Perbedaan hasil pengujian diduga sangat dipengaruhi oleh ukuran fisik bahan mentah. Arabushi cakalang diolah dari ikan yang bobotnya di atas 2,5 kg/ekor, sedangkan arabushi tongkol dengan bobot 0,5-1,5 kg/ekor. Akumulasi fenol pada ikan cakalang lebih cepat dibandingkan tongkol. Ternyata perbedaan bobot ikan yang dipakai telah menyebabkan kadar fenol berbeda nyata, sedangkan penurunan kadar air lebih cepat terjadi pada ikan tongkol. Penurunan kadar air pada pengolahan arabushi cakalang adalah 223,9\% (bk = bobot kering), sedangkan pada arabushi tongkol adalah 262,5\%bk. Perbedaan kecepatan penurunan kadar air tersebut berpengaruh terhadap penurunan nilai $\mathrm{a}_{\mathrm{w}}$. Penurunan nilai $\mathrm{a}_{\mathrm{w}}$ pada arabushi cakalang sebesar 7,5\% dan arabushi tongkol sebesar 10,6\%. Pada kisaran nilai a 0,84-0,86 (Tabel 1) bakteri pembusuk sudah dapat dipastikan tidak akan tumbuh, tetapi beberapa jenis kelompok kapang akan tumbuh pada kedua permukaan arabushi, khususnya

Tabel 1. Komposisi proksimat, nilai $\mathrm{a}_{\mathrm{w}}$ dan $\mathrm{pH}$ ikan cakalang dan tongkol dalam bentuk segar, arabushi dan katsuobushi.

Table 1. Proximate composition, $a_{\text {w }}$ and $p H$ value of skipjack tuna and frigate mackerel in fresh, arabushi and katsuobushi forms.

\begin{tabular}{|c|c|c|c|c|c|c|}
\hline \multirow{2}{*}{$\begin{array}{l}\text { Parameter } \\
\text { Parameters }\end{array}$} & \multicolumn{2}{|c|}{ Ikan segar (Freshfish) } & \multicolumn{2}{|c|}{ Arabushi } & \multicolumn{2}{|c|}{ Katsuobushi } \\
\hline & $\begin{array}{l}\text { Cakalang } \\
\text { K. pelamis }\end{array}$ & $\begin{array}{l}\text { Tongkol } \\
\text { A. thazard }\end{array}$ & $\begin{array}{l}\text { Cakalang } \\
\text { K. pelamis }\end{array}$ & $\begin{array}{c}\text { Tongkol } \\
\text { A. thazard }\end{array}$ & $\begin{array}{l}\text { Cakalang } \\
\text { K. pelamis }\end{array}$ & $\begin{array}{c}\text { Tongkol } \\
\text { A. thazard }\end{array}$ \\
\hline $\begin{array}{l}\text { Kadar air }(\% \mathrm{bk}) \\
\text { Moisture content }(\% \mathrm{db})\end{array}$ & 250.02 & 285.06 & 26.1 & 22.6 & 31.2 & 19.5 \\
\hline $\begin{array}{l}\text { Protein kasar (\%bk) } \\
\text { Crude protein }(\% \mathrm{db})\end{array}$ & 82.43 & 84.79 & 90.76 & 92.71 & 89.78 & 84.71 \\
\hline $\begin{array}{l}\text { Kadar lemak }(\% \mathrm{bk}) \\
\text { Fat content }(\% \mathrm{db})\end{array}$ & 2.59 & 1.96 & 4.16 & 2.7 & $\mathrm{td}$ & $\mathrm{td}$ \\
\hline $\begin{array}{l}\text { Kadar abu }(\% \mathrm{bk}) \\
\text { Ash content }(\% \mathrm{db})\end{array}$ & 8.16 & 5.47 & 3.96 & 4.32 & $\mathrm{td}$ & $\mathrm{td}$ \\
\hline $\begin{array}{l}\text { Fenol }(\% \mathrm{bk}) \\
\text { Phenol content }(\% \mathrm{db})\end{array}$ & & & 10.21 & 5.17 & 4.9 & 3.8 \\
\hline $\begin{array}{l}\mathrm{a}_{\mathrm{w}} \\
\mathrm{pH}\end{array}$ & 0.93 & 0.94 & $\begin{array}{c}0.86 \\
-\end{array}$ & $\begin{array}{l}0.84 \\
6.14\end{array}$ & 0.865 & 0.812 \\
\hline
\end{tabular}

$\mathrm{td}=$ tidak dianalisis $($ not analized) 
kelompok A. glaucus (Raper \& Fennell, 1973; Pitt \& Hocking, 1985; Samson et al., 1995).

Pada akhir fermentasi terjadi penurunan kadar air dan kadar fenol masing-masing 0,98\% dan 5,3\% untuk katsuobushi cakalang, serta 8,0\% dan 1,4\% untuk katsuobushi tongkol. Kadar air dan nilai $a_{w}$ meningkat sebesar $5,1 \%$ bk dan $0,9 \%$ untuk cakalang, serta sebesar $3,1 \%$ bk dan $3,3 \%$ untuk katsuobushi tongkol.

\section{Pembuatan katsuobushi}

Selama proses fermentasi menjadi katsuobushi, kadar air arabushi cakalang cenderung konstan hingga fermentasi tahap III, sedangkan kadar air arabushi tongkol meningkat dan mencapai maksimum pada fermentasi tahap III (Gambar 2). Pada fermentasi tahap IV, kadar air arabushi cakalang meningkat. Peningkatan kadar air yang terjadi pada kedua arabushi diduga adalah sebesar $6,08 \%$ bk yang diukur dari fermentasi tahap I hingga tahap III. Pada fermentasi lebih lanjut terjadi penurunan kadar air baik untuk arabushi cakalang maupun arabushi tongkol.

Kapang dalam memacu pertumbuhannya tidak hanya dipengaruhi oleh ketersediaan nutrisi dari arabushi tetapi juga oleh suhu dan jumlah uap air di dalam ruangan fermentasi. Menurut Adnan (1982), kebutuhan air untuk pertumbuhan kapang akan lebih besar bila air yang digunakan untuk pertumbuhan diperoleh dengan cara absorbsi dibandingkan dengan sejumlah air yang diperoleh secara desorbsi. Pada arabushi cakalang kemungkinan kadar air yang dibutuhkan untuk tumbuh maksimum belum memadai sehingga sejumlah uap air yang diserap dari ruangan fermentasi jumlahnya lebih tinggi dibandingkan dengan arabushi tongkol. Hasil perhitungan jumlah rata-rata uap air per $1 \mathrm{~kg}$ udara kering

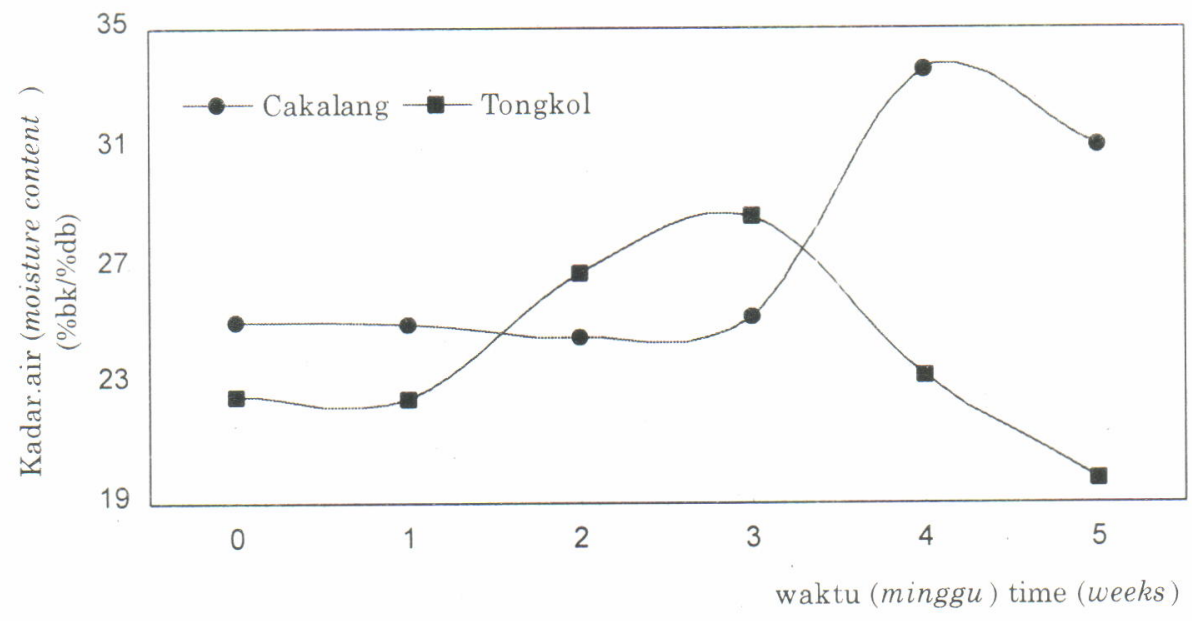

Gambar 2. Fluktuasi kadar air selama tahap fermentasi.

Figure 2. Changes of moisture content during fermentation process.

akibat sejumlah uap air yang ada dalam ruangan fermentasi terserap ke dalamnya. Adanya perbedaan kecepatan absorbsi uap air kemungkinan disebabkan oleh perbedaan tekstur daging, kadar air, dan kadar lemak awal. Hasil pengujian ditemukan bahwa kadar air dan lemak arabushi tongkol lebih kecil daripada arabushi cakaláng, sehingga pada saat dilakukan fermentasi dalam ruangan kedap udara kecepatan absorbsi uap air lebih cepat terjadi pada arabushi tongkol. Absorbsi uap air oleh arabushi cakalang adalah sebesar $8,46 \%$ bk yang dihitung dari fermentasi tahap I hingga tahap IV, sedangkan oleh arabushi tongkol pada ruangan fermentasi, untuk arabushi tongkol lebih besar dari arabushi cakalang (Tabel 2). Kelebihan uap air pada ruangan fermentasi tersebut diduga telah mempercepat proses absorbsi uap air ke arabushi tongkol sehingga dapat dimanfaatkan untuk pertumbuhan kapang. Sebaliknya penyerapan uap air ke arabushi cakalang lebih lambat yang mengakibatkan pertumbuhan kapang menjadi lambat dan tidak dapat merata di permukaan arabushi.

Hasil pengamatan menunjukkan bahwa nilai $a_{w}$ berkorelasi positif dengan peningkatan kadar air (Gambar 3). Kadar air produk cakalang hingga 
Tabel 2. Perubahan kelembaban dan jumlah uap air per kg udara kering selama pengamatan $4 \times 24$ jam.

Table 2. Changes of relative air humidity and total moisture content per kg dry air during $4 x$ 24 hours observation.

\begin{tabular}{|c|c|c|c|c|}
\hline & \multicolumn{4}{|c|}{ Jenis ikan kayu (Type of arabushi) } \\
\hline & Kat & $\begin{array}{l}\text { Cakalang } \\
\text { uwonus pelamis }\end{array}$ & & $\begin{array}{c}\text { Tongkol } \\
\text { Auxis thazard }\end{array}$ \\
\hline $\begin{array}{c}\text { Pengamatan } \\
\text { Observation }\end{array}$ & $\% \mathrm{RH}$ & $\begin{array}{c}\text { Uap air } \\
\text { (g/kg udara kering) } \\
\text { Moisture } \\
(\mathrm{g} / \mathrm{kg} \text { dry air })\end{array}$ & $\% \mathrm{RH}$ & $\begin{array}{c}\text { Uap air } \\
\text { (g/kg udara kering) } \\
\text { Moisture } \\
(\mathrm{g} / \mathrm{kg} \text { dry air })\end{array}$ \\
\hline Maksimum (Maximum) & 96 & 24.11 & 96 & 25.95 \\
\hline Minimum (Minimum) & 90.7 & 22.06 & 90.43 & 19.46 \\
\hline Rata-rata (Average) & 95.07 & 22.37 & 95.2 & 22.75 \\
\hline $\begin{array}{l}\text { Rata-rata uap air di udara } \\
\text { Average water vapor in air }\end{array}$ & \multicolumn{4}{|c|}{$21 \mathrm{~g} / \mathrm{kg}$ udara kering ( $\mathrm{g} / \mathrm{kg}$ dry air) } \\
\hline
\end{tabular}

tahap IV fermentasi meningkat sebanyak 8,46\% dan nilai $\mathrm{a}_{\mathrm{w}}$ meningkat sebanyak $1,74 \%$. Nilai $\mathrm{a}_{\mathrm{w}}$ yang tinggi pada arabushi cakalang adalah sangat riskan, karena pada nilai $a_{w}$ sebesar 0,88 memungkinan bakteri xeropilik berkembang biak dan mengubah hasil degradasi protein oleh kapang menjadi akumulasi amonia. Hal ini terbukti bahwa produk menjadi lembab dan mengeluarkan bau amonia. Sebaliknya pada fermentasi tongkol kadar air turun sebanyak 3,7\%bk dan diikuti oleh penurunan nilai $\mathrm{a}_{\mathrm{w}}$ sebanyak $1,8 \%$. Terjadinya perbedaan ini disebabkan oleh perbedaan tingkat kelembaban, jumlah uap air dalam ruangan fermentasi dan perbedaan komposisi kimia arabushi sebelum diperlakukan.

Fluktuasi faktor internal (kadar air, dan nilai $a_{w}$ ) dan faktor eksternal (suhu, oksigen, tingkat kelembaban dan jumlah uap air dalam ruangan fermentasi) berpengaruh negatif terhadap kemampuan kapang melakukan degradasi kadar fenol, protein dan kandungan lemak. Peningkatan nilai $\mathrm{a}_{\mathrm{w}}$ dan kadar air pada produk cakalang telah menyebabkan terjadinya beberapa perubahan pada produk, antara lain terciumnya bau amonia yang agak kuat karena bakteri/kapang pembusuk telah mulai aktif memanfaatkan asam-asam

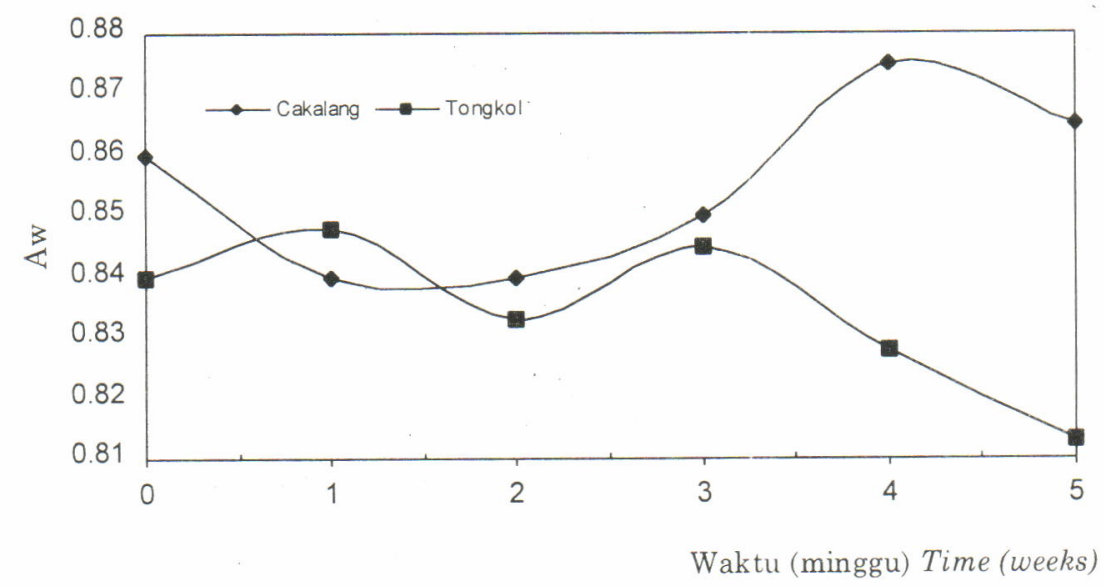

Gambar 3. Perubahan nilai a $\mathrm{a}_{\mathrm{w}}$ selama proses fermentasi dalam desikator.

Figure 3. Changes of $a_{w}$ value during fermentation process in desiccator. 
amino hasil degradasi tahapan fermentasi sebelumnya sebagai sumber energi untuk membelah diri dan sebagai hasil aktivitasnya telah tercium bau amonia.

Produk tongkol sebelum memasuki fermentasi tahap IV dikeringkan dengan matahari dan pada dasar kotak tidak diberi air. Setelah fermentasi tahap IV ternyata bau amonia tidak terdeteksi dan produk tidak lembab. Namun demikian pertumbuhan kapangnya menjadi lebih lama jika dibandingkan dengan fermentasi cakalang, karena produk terlalu kering dan selama proses fermentasi tahap IV terjadi peristiwa desorbsi uap air dari produk tongkol ke ruangan fermentasi sebanyak 9,0\%bk. Desorbsi ini telah menyebabkan penurunan nilai $a_{\mathrm{w}}$ dari 0,85 menjadi $0,83(2,01 \%$ penurunan).

Fluktuasi kadar air dan nilai $\mathrm{a}_{\mathrm{w}}$ berpengaruh negatif terhadap penurunan nilai fenol. Kadar fenol tersisa setelah fermentasi tahap III, adalah $5,5 \%$ untuk katsuobushicakalang dan 4,3\% untuk Katsuobushi tongkol. Doi et al. (1989a) menyatakan bahwa senyawa fenol pada fermentasi menggunakan $A$. repens MA0197 diubah menjadi produk turunannya seperti mono-, di-, dan trimetilasi yang merupakan salah satu precursor pembentukan citarasa katsuobushi. Pada arabushi cakalang setelah fermentasi tahap I kadar fenol yang tersisa 5,7\% sedangkan pada arabushi tongkol 4,5\% (Gambar 4). Hasil tersebut membuktikan bahwa pada kisaran nilai a antara 0,84-0,86 pada arabushi cakalang dan pada arabushi tongkol adalah 0,83-0,84 merupakan kisaran $\mathrm{a}_{\mathrm{w}}$ optimum untuk mendegradasi senyawa fenol.
Nilai $a_{w}$ yang merupakan barometer untuk mengukur aktivitas kapang menunjukkan kecenderungan peningkatan pada produk cakalang, sedangkan pada produk tongkol menunjukkan kecendrungan penurunan selama proses fermentasi berlangsung. Adanya kontradiksi yang berlainan inilah yang menyebabkan terjadinya perbedaan waktu fermentasi dan sebagai konsekuensinya komposisi asam-asam amino yang dihasilkan juga berbeda. Pada katsuobushi cakalang jumlah protein kasar yang dapat diuraikan menjadi sejumlah asam amino mengalami penurunan sebesar $0,25 \%$ bk. Kandungan asam amino arabushi cakalang sebesar $8,99 \%$ bk dan setelah fermentasi tahap I turun menjadi $8,74 \%$ bk, kemudian setelah fermentasi dilanjutkan hingga tahap V terjadi peningkatan sebesar $4,70 \% \mathrm{bk}$. Sebaliknya hasil degradasi protein menjadi asam asam amino pada arabushi tongkol berbeda sangat nyata dari sebesar $13,58 \%$ bk pada produk arabushi menjadi 59,91\%bk setelah fermentasi tahap I dan kemudian setelah fermentasi dilanjutkan hingga tahap $V$ protein kasar yang dapat didegradasi menjadi asam-asam amino sebesar $80,75 \%$ bk. Beberapa jenis asam amino telah rusak selama fermentasi arabushi cakalang antara lain: leusin, phenilalanin dan alanin (Tabel 3). Sedangkan pada katsuobushi tongkol terjadi peningkatan yang berarti pada sejumlah asam amino seperti aspartat, histidin, leusin, fenilalanin, sistin, dan threonin. Terbukti peranan jenis kapang yang tumbuh di setiap permukaan arabushi selama proses fermentasi berpengaruh terhadap kuantitas asam-asam amino yang dihasilkan. Pada Tabel 3 dapat dilihat proporsi

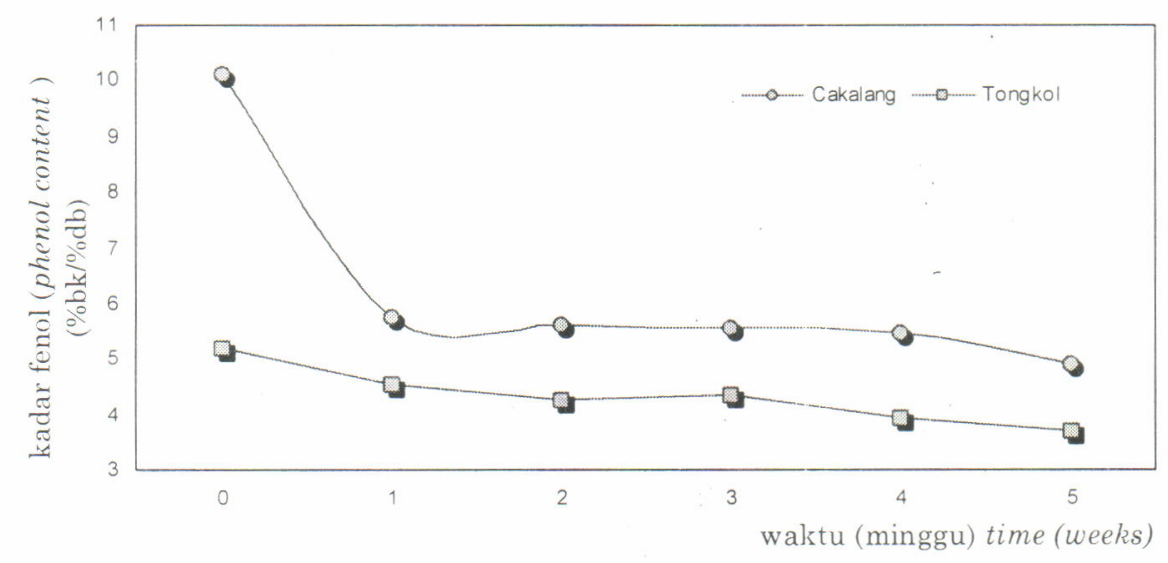

Gambar 4. Fluktuasi kadar fenol selama proses fermentasi dalam ruangan desikator. Figure 4. Fluctuation of phenol content during fermentation process in desiccator. 
Tabel 3. Komposisi asam amino pada produk katsuobushi cakalang dan tongkol. Table 3. Amino acid compotition of skipjack tuna and frigate mackerel katsuobushi.

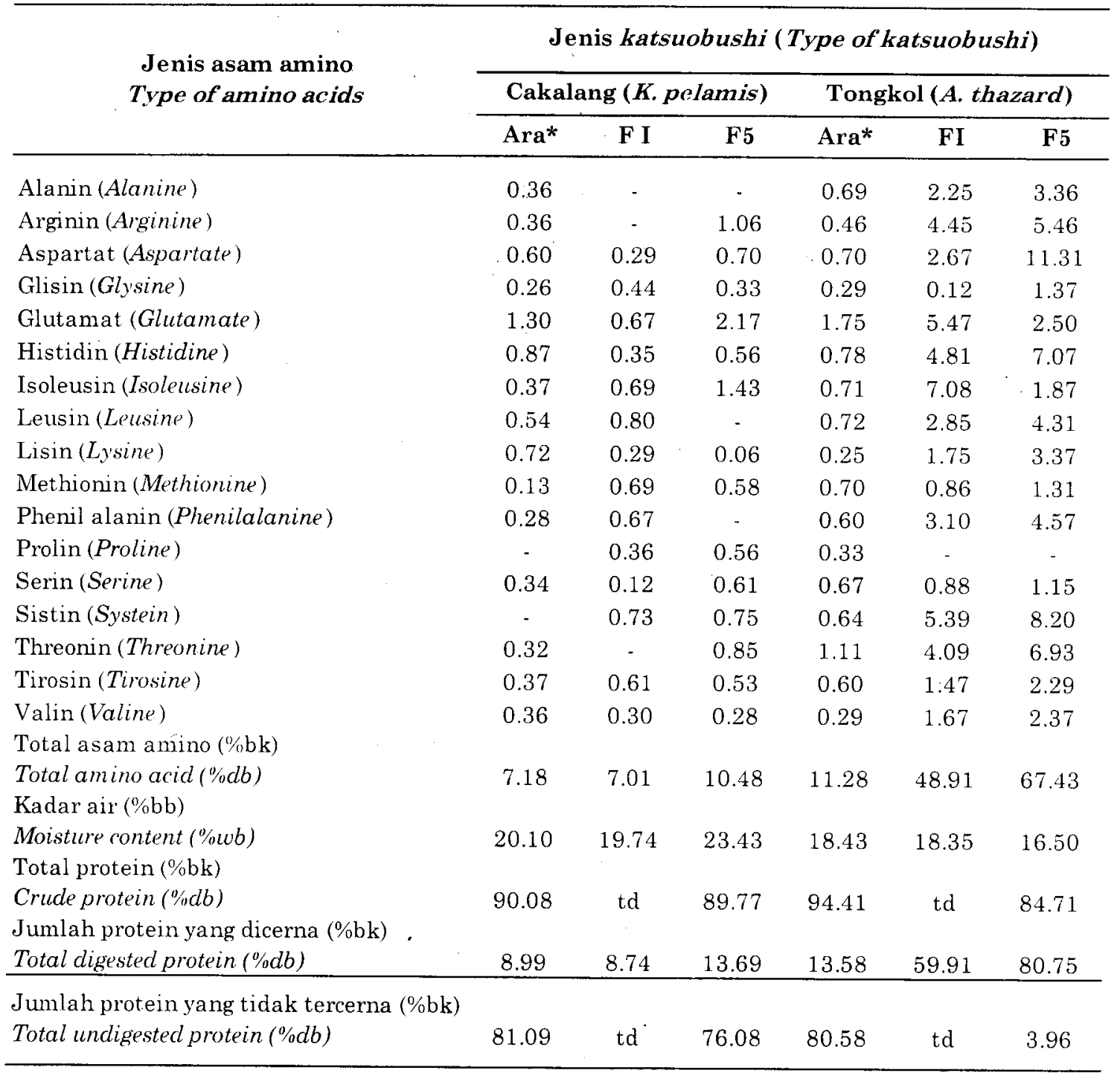

F1 fermentasi tahap 1 (first step fermentation); F5 = fermentasi tahap V (fifth step fermentation): Ara * arabushi; $\mathrm{td}=$ tidak dianalisis (not analized)

jumlah asam amino yang telah dihasilkan selama proses fermentasi.

Protein tercerna (digested protein) menjadi asam-asam amino tidak terlepas dari peranan kapang yang tumbuh pada permukaan arabushi dan kemampuannya untuk mendegradasi protein menjadi asam-asam amino. Pada Tabel 3 terbukti bahwa kapang alami yang tumbuh pada permukaan katsuobushi tongkol mempunyai ke-. mampuan yang lebih besar mendegradasi protein menyadi asam-asam amino dibandingkan dengan kapang vang tumbuh pada permukaan katsuobushi cakalang. Setelah fermentasi tahap V jumlah asam amino pada katsuobushi tongkol adalah $80,75 \%$ dan pada katsuobushi cakalang adalah $13,58 \%$. Terbukti bahwa ukuran arabushi, jenis kapang yang tumbuh sangat berpengaruh terhadap kecepatan degradasi protein menjadi asam-asam amino.

Faktor lain yang ikut menunjang aktivitas kapang untuk mendegradasi protein menjadi asam-asam amino adalah faktor internal (internal factors) seperti perbedaan nilai $a_{w}$, kadar air, kandungan awal protein (Tabel 1) dan faktor ekternal (external factors) seperti tingkat kelembaban relatif udara, suhu dan jumlah uap air yang ada dalam ruangan fermentasi. Hasil identifikasi jenis-jenis kapang yang tumbuh pada 
kedua permukaan arabushi selama proses fermentasi berlangsung dan yang paling dominan sejak fermentasi tahap I hingga tahap II pada arabushi tongkol adalah kombinasi $A$. flavus dan Penicillium citrinum, sedangkan pada arabushi cakalang pada tahap I dan II fermentasi telah didominasi oleh kapang Erotium repens, Penicillium spp. dan $A$. flavus. Kemudian pada tahap III dan IV kedua produk yang difermentasikan telah didominasi oleh $A$. flauus dan $P$. citrinum. Adanya kombinasi pertumbuhan positive synergism antara $A$. flavus dan $P$. citrinum telah dapat meningkatkan jumlah asam amino pada katsuobushi tongkol, sedangkan pada katsuobushi cakalang meskipun pada tahap III dan IV fermentasi telah ditumbuhi oleh $A$. flavus dan $P$. kadar fenol selama proses fermentasi yakni kadar fenol katsuobushi cakalang setelah fermentasi tahap V tersisa sebesar 4,9\%bk, dan katsuobushi tongkol tersisa sebesar $3,8 \% \mathrm{bk}$.

Jumlah protein kasar yang telah terdegradasi menjadi asam-asam amino pada katsuobushi cakalang sebesar 13,69\% (bk), sedangkan pada katsuobushi tongkol sebesar $80,75 \%$ bk. Beberapa asam amino telah rusak selama fermentasi tahap $\mathrm{V}$ seperti alanin, leusin, dan fenilalanin pada katsuobushi cakalang, sedangkan prolin telah rusak pada katsuobushi tongkol selama fermentasi tahap V. Secara keseluruhan nilai gizi katsuobushi tongkol lebih baik daripada katsuobushi cakalang.

Tabel 4. Jenis-jenis kapang yang tumbuh pada permukaan arabushi selama tahapan fermentasi.

Table 4. Types of mould growth on surfaces of skipjack tuna and frigate mackerel arabushi during fermentation.

\begin{tabular}{|c|c|c|}
\hline \multirow{2}{*}{$\begin{array}{c}\text { Tahapan } \\
\text { fermentasi } \\
\text { Steps of } \\
\text { fermentation }\end{array}$} & \multicolumn{2}{|c|}{ Jenis arabushi (Types of arabushi) } \\
\hline & $\begin{array}{c}\text { Cakalang } \\
\text { Skipjack tuna }\end{array}$ & $\begin{array}{c}\text { Tongkol } \\
\text { Frigate mackerel }\end{array}$ \\
\hline \multirow[t]{2}{*}{ I } & E. repens & P. citrinum \\
\hline & Penicillium spp. & A. flavus \\
\hline II & $\begin{array}{l}\text { E. repens } \\
\text { A. flavus }\end{array}$ & $\begin{array}{l}\text { P. citrinum } \\
\text { A. flavus }\end{array}$ \\
\hline \multirow[t]{2}{*}{ III } & A. flavus & A. flavus \\
\hline & P. citrinum & P. citrinum \\
\hline \multirow[t]{2}{*}{ IV } & A. flavus & A. flavus \\
\hline & P. citrinum & $P$. citrinum \\
\hline
\end{tabular}

citrinum ternyata tidak dapat meningkatkan jumlah asam amino. Hal ini disebabkan karena kombinasi $E$. repens dan $A$. flavus banyak menghasilkan metabolik yang bersifat toksik untuk kapang yang akan tumbuh pada fermentasi tahap selanjutnya. Pada Tabel 4 dapat dilihat komposisi jenis-jenis kapang yang tumbuh selama fermentasi.

\section{KESIMPULAN}

Kecepatan reduksi kadar air dan nilai a $\mathrm{w}_{\mathrm{w}}$ dalam pembuatan arabushi sangat tergantung pada ukuran atau jenis ikan, sedangkan kadar fenol yang dapat disubstitusi dengan kadar air adalah lebih besar selama pembuatan arabushi cakalang.

Selama fermentasi dalam desikator terbukti antara kadar air dan nilai $\mathrm{a}_{\mathrm{w}}$ mempunyai korelasi positif yang mengakibatkan terjadinya penurunan
Jenis kapang yang umum tumbuh pada kedua produk katsuobushi adalah dari kelompok Aspergillus yakni $A$. flavus dan E. repens, sedangkan dari kelompok Penicillium adalah $P$. citrinum.

\section{Saran}

Titik kritis yang perlu diperhatikan pada fermentasi alami adalah pada saat memasuki fermentasi tahap IV dan V. Untuk mengatasi masalah tersebut setiap akhir tahapan fermentasi produk dijemur kurang lebih 120 menit agar sejumlah uap air yang menempel pada permukaan produk dapat dihilangkan dan kemudian diikuti pada fermentasi tahap IV dan $\mathrm{V}$ dengan ruangan fermentasi tidak perlu dilembabkan kembali menggunakan air 


\section{DAFTAR PUSTAKA}

Adnan, M. 1982. Aktivitas Air dan Kerusakan Bahan Makanan. Penerbit Agritech, Yogyakarta. 21-22.

Anonimous. 1974. Metode dan Prosedur Pemeriksaan Kimiawi Hasil Perikanan. Lembaga Teknologi Perikanan, Jakarta. 3-14.

Basmal, J., Indriati, N., Nasran, S. dan Hak, N. 1997a. Penelitian Pendahuluan Pengolahan Katsuobushi dari Ikan Cakalang (Katsuwonus pelamis) Secara Alami. Tidak diterbitkan.

Basmal, J. dan Nasran, S. 1997b. Respon Pertumbuhan Kapang di Permukaan Ikan Kayu (Kamebushi) Pada Kelembaban Relatif Udara Terkontrol. Tidak diterbitkan.

Doi. M., Matsui, M., Shuto, Y. and Kinoshita, Y. 1989a Degradation and o-methylation of phenols among volatile flavor compounds of dried Bonito (katsuobushi) by Aspergillus species. Agric. Biol. Chem. 53(4):1051-1055.

Doi. M. 1989b. )-methylation of phenols by Aspergillus repens MA0197. Agric. Biol. Chem. 53(11):3031. 3032.

Doi. M. 1990. Biological isomerization of cyclohexanols by Aspergillus repens MA0197. Agric. Biol. Chem 54(5) 1177.1181

Hanafiah, T.A.R., Winarno, B.I. dan Marasabessy, H. 1984. Pengamatan pada proses pembuatan ikan kayu cakalang (Katsuwonus pelamis). Jurnal Pen. Pascapanen Perikanan. 27:15-22.
Horwitz. W., 1980. Official Methods of Analysis of the Assosiation of Official Analitycal Chemist. Benjamin Franklin Station, Washington D.C. 71 -

Nasran, S., dan Irianto, H.E. 1987. Penelitian pengolahan ikan kayu. Jurnal Pen. Pascapanen Perikanan 58: 31-38.

Nasran, S. 1988. Pengolahan ikan kayu (Katsuobushi). Kumpulan Hasil Penelitian Teknologi Pasca Panen Perikanan, Buku I. Balai Penelitian Teknologi Perikanan. Jakarta. 45-48.

Pitt. J.I. and Hocking, A.D. 1985. Fungi and Food Spoilage. Text book. Academic Press. Tikyo. 48-53.

Raper, K.B. and Fennell, D.I. 1973. Aspergillus group. The Genus Aspergillus. Texbook. Robert E. Krieger Publishing Company Huntington, New York. P: 190 - 191.

Sakakibara, H., Hosokawa, M., Yajima, I. and Hayashi, K. 1990. Flavor constituents of dried Bonito (katsuobushi). Food Review International, 6(4):553572.

Samson, R.A., Hocking, E.S., Jens C Frisvad and Ole Filterborg. 1995. Indtoduction to Food-borne Fungi. 4 th edition. Central Bureau voor Schimmelcultures. Netherlands. P: 235-289.

Tanikawa, E. 1971. Marine Product in Japan, Koseisha Okseikaku. Co. Ltd. Tokyo. 246-252.

Winarno, F.G., Fardiaz, S. dan Fardiaz, D. 1980. Pengantar Teknologi Pangan. Penerbit PT. Gramadia Jakarta. 59-62. 